\title{
Fast Formation of Nitro-PAHs in the Marine Atmosphere Constrained in a Regional-Scale Lagrangian Field Experiment
}

Marie D. Mulder, ${ }^{\dagger,}$ Yetkin Dumanoglu, ${ }^{\S}$ Christos Efstathiou, ${ }^{\dagger, \bigcirc}$ Petr Kukučka, ${ }^{\dagger}$ Jana Matejovičová, ${ }^{\dagger} \|$ Christian Maurer, ${ }^{\ddagger}$ Petra Pribylová ${ }^{\dagger}$ Roman Prokeš, ${ }^{\dagger}$ Aysun Sofuoglu, ${ }^{\perp}$ Sait C. Sofuoglu, ${ }^{\perp, \#}$ Jake Wilson, ${ }^{\nabla}$ Cornelius Zetzsch, ${ }^{\nabla}$ Gerhard Wotawa, ${ }^{\dagger}$ and Gerhard Lammel ${ }^{* \dagger, \nabla_{\odot}}$

${ }^{\dagger}$ Masaryk University, Research Centre for Toxic Compounds in the Environment, Kamenice 5, 625 00, Brno, Czech Republic

$\ddagger$ Zentralanstalt für Meteorologie und Geodynamik, Wien, Austria

${ }^{\S}$ Dokuz Eylül University, Environmental Engineering Dept., Izmir, Turkey

"Slovak Hydrometeorological Institute, Bratislava, Slovakia

${ }^{\perp}$ Izmir Institute of Technology, Chemical Engineering Dept., Urla, Turkey

${ }^{\#}$ Izmir Institute of Technology, Environmental Engineering Dept., Urla, Turkey

${ }^{\nabla}$ Max Planck Institute for Chemistry, Multiphase Chemistry Dept., Mainz, Germany

Supporting Information

\begin{abstract}
Polycyclic aromatic hydrocarbons (PAHs) and some of their nitrated derivatives, NPAHs, are seemingly ubiquitous in the atmospheric environment. Atmospheric lifetimes may nevertheless vary within a wide range, and be as short as a few hours. The sources and sinks of $\mathrm{NPAH}$ in the atmosphere are not well understood. With a Lagrangian field experiment and modeling, we studied the conversion of the semivolatile PAHs fluoranthene and pyrene into the 2nitro derivatives 2-nitrofluoranthene and 2-nitropyrene in a cloud-free marine atmosphere on the time scale of hours to 1 day between a coastal and an island site. Chemistry and transport during several episodes was simulated by a Lagrangian box model i.e., a box model coupled to a Lagrangian particle dispersion model, FLEXPART-WRF. It is found that the chemical kinetic data do capture photochemical degradation of the 4-ring PAHs under ambient conditions on the time scale of hours to 1 day, while the production of the corresponding NPAH, which sustained 2-nitrofluoranthene/ fluoranthene and 2-nitropyrene/pyrene yields of $(3.7 \pm 0.2)$ and $(1.5 \pm 0.1) \%$, respectively, is by far

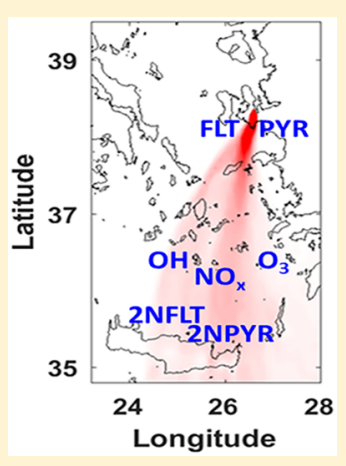
underestimated. Predicted levels of NPAH come close to observed ones, when kinetic data describing the reactivity of the $\mathrm{OH}$-adduct were explored by means of theoretically based estimates. Predictions are also underestimated by $1-2$ orders of magnitude, when NPAH/PAH yields reported from laboratory experiments conducted under high $\mathrm{NO}_{x}$ conditions are adopted for the simulations. It is concluded that $\mathrm{NPAH}$ sources effective under low $\mathrm{NO}_{x}$ conditions, are largely underestimated.
\end{abstract}

\section{INTRODUCTION}

Polycyclic aromatic hydrocarbons (PAHs) and their alkylated, nitrated (NPAHs) and oxygenated (OPAHs) derivatives in the atmospheric environment are of concern because of harmful effects on human health ${ }^{1-4}$ and ecosystems. ${ }^{5,6}$ PAHs and their derivatives are formed in all types of combustion processes, and also petrogenic sources can be significant. The parent $\mathrm{PAHs}^{7-10}$ and NPAHs ${ }^{11-15}$ are ubiquitous in the atmospheric environment, including the world oceans ${ }^{16-18}$ and polar regions. ${ }^{19-21} \mathrm{NPAHs}$ distribute across environmental compartments and they may revolatilize. ${ }^{22}$ Nevertheless, many of these substances are usually transformed within hours depending on the abundance of oxidants and solar radiation. ${ }^{9}$ The nitrated derivatives' biological effects often are stronger than those of the parent PAHs, which has been documented for the mutagenicity of fluoranthene (FLT), pyrene (PYR), chrysene, and benzanthrone ${ }^{4,22-25}$ and for developmental toxicity of phenanthrene, anthracene, PYR, and benzanthrone. ${ }^{26}$ Nitra- tion may also turn a $\mathrm{PAH}$ into a precursor of reactive oxygen species in the epithelial lung fluid ${ }^{3,27,28}$ and, hence, add to oxidative stress and damage and, ultimately, related chronic diseases.

Most PAHs partition between the gaseous and particulate phases of aerosols to a significant extent ${ }^{29,30}$ and are subject to revolatilization from land and sea surfaces. ${ }^{18,31-34} \mathrm{PAH}$ atmospheric fate is complex and incompletely understood. Major knowledge gaps are chemical kinetics and pathways of the homogeneous gas-phase and of multiphase reactions in aerosols, $9,32,35-37$ whereas phase partitioning and deposition processes are consistently described. ${ }^{30,38-40}$ Many NPAHs are the products of the chemical transformations of $\mathrm{PAH}$ that

Received: $\quad$ March 4, 2019

Revised: June 25, 2019

Accepted: June 26, 2019

Published: June 26, 2019 
occur in the atmosphere during both day- and night-time. Some NPAHs are indicative products of certain chemical transformation pathways, whereas others are directly emitted from primary combustion sources. ${ }^{9,41-47}$

Modeling studies of PAHs have so far been overwhelmingly focused on benzo(a)pyrene, a 5-ring $\mathrm{PAH}$ (e.g., refs 37, and 48-52). Benzo(a)pyrene is a criteria pollutant in many countries and used as a representative substance for parent PAHs or even polycyclic aromatic compounds as a whole. The nitrated derivatives of PAHs are however not designated as a criteria/regulated pollutant. The fate of semivolatile PAHs in ambient air is significantly influenced by gas-particle partitioning and air-surface exchange. It has so far been addressed by modeling studies mostly on large spatial and temporal scales (weeks and longer),,$^{7,10,53-56}$ while the understanding on time scales of hours to days has hardly ever been validated by modeling. The transformation of PAHs into derivatives, NPAH or OPAH, has so far been studied with regard to long-term multicompartmental distribution under steady state conditions ( $2-4$ ring $\mathrm{PAHs}){ }^{22}$ but not dynamically. FLT and PYR as well as their nitrated derivatives are toxic ${ }^{4,57,58}$ and the latter are long-lived and, probably, ubiquitous. $^{11,12}$

Long-range transport from urban and industrial sources on land are the predominant sources of PAHs in the Mediterranean. ${ }^{59-61}$ In the present study, the aim is to investigate NPAH formation on time scales of hours $(<1$ day) under ambient conditions. Specifically, we focus on the fate of the truly semivolatile 4-ring PAHs FLT and PYR and the formation of NPAH derivatives based on measurements at a coastal source site and a remote receptor site in the Eastern Mediterranean, using coupled box and Lagrangian dispersion modeling (Lagrangian box model).

\section{MATERIALS AND METHODS}

2.1. Sites. During a coordinated field experiment, held in summer 2012, focusing on cycling of PAHs and POPs in the Aegean, ${ }^{32,33}$ simultaneous samples were taken at a rural station, Urla, at the western margin of the metropolitan area of Izmir, Turkey ( $\approx 4.3$ million inhabitants), and at Finokalia, on the Cretan north coast. The region spanned between these two sites, direct distance $340 \mathrm{~km}$, is the southeastern part of the Aegean Sea with very few islands and little ship traffic.

The rural site, Urla $\left(38.3^{\circ} \mathrm{N} / 26.6^{\circ} \mathrm{E}\right)$, is about $45 \mathrm{~km}$ westsouthwest from the center of Izmir. The marine background site on Crete, Finokalia $\left(35.3^{\circ} \mathrm{N} / 25.7^{\circ} \mathrm{E}\right)$, is located on a cliff on the north coast of the island, some $20 \mathrm{~km}$ away of any anthropogenic emissions and $70 \mathrm{~km}$ east of major anthropogenic emissions (Iraklion, a city of 100000 inhabitants with airport and industries). ${ }^{62,63}$ During the campaign, the northerly air flow determined that Urla is the upwind (i.e., source) and Finokalia is the downwind (i.e., receptor) site.

2.2. Sampling and Analysis. At Urla, gaseous and particulate phases were collected with a midvolume sampler (Thermo-Andersen, model GPS-11, $F \approx 15 \mathrm{~m}^{3} / \mathrm{h}$ ) and at Finokalia with a high-volume sampler (model HVS110, Baghirra, Prague, $F \approx 68 \mathrm{~m}^{3} / \mathrm{h}$ ) equipped with a cascade impactor (Andersen, $\mathrm{PM}_{10}$ inlet, cutoffs 7.2, 3.0, 1.5, 0.95, 0.45 $\mu \mathrm{m}$ of aerodynamic particle diameter and back-up filter). At Urla, gases and particles (TSP) were collected on glass fiber filter and polyurethane foam (PUF) plugs. The sampling times were day-time $(\approx 9 \mathrm{~h})$ and nighttime $(\approx 14 \mathrm{~h})$, start times given by sunrise and sunset during 2-13 July 2012 .
At Finokalia, two PUF plugs (Gumotex, Břeclav, Czech Republic, density $0.030 \mathrm{~g} \mathrm{~cm}^{-3}, 110 \mathrm{~mm}$ diameter, cleaned by extraction in acetone and dichloromethane, $8 \mathrm{~h}$ each, placed in a glass cartridge) were placed in series downstream of the impactor. The particles were collected on preheated $\left(480{ }^{\circ} \mathrm{C}\right)$, slotted quartz fiber filters (Environmental Tisch TE-230QZ) and on the backup filter (Whatman QMA $254 \times 203 \mathrm{~mm}$ ). Sampling frequencies were 12 hly for gaseous and 24-48 hly for size-resolved particulate fractions.

PM mass concentration at the receptor site was derived from optical particle counting (32 bins $>0.25 \mu \mathrm{m}$, Grimm model 1.105 , Ainring, Germany; sphericity assumption). Meteorological parameters (air temperature, humidity, wind direction and velocity) and many other supporting parameters were available at Finokalia. ${ }^{33}$

PAHs and NPAHs were analyzed by gas-chromatography/ mass spectrometry in total organic extracts of filter and PUF plug samples. The extraction, cleanup, and chromatographic methods are described, and the QA parameters given in the Supporting Information (SI) S1.

$\mathrm{OM}$ and $\mathrm{BC}$ were analyzed in punches of TSP GFF filter samples collected at Urla. OM was determined by burning the filters at $550{ }^{\circ} \mathrm{C}$ for $6 \mathrm{~h}$. The $\mathrm{BC}$ analysis was run in a transmissometer (Magee, model OT21).

2.3. Atmospheric Transport Modeling. 2.3.1. Model Setup. The Lagrangian particle dispersion model FLEXPARTWRF was run for every of the 22 sampling times at the source site. Analyzed wind fields (ECMWF reanalyses, $0.25^{\circ}$ resolution) were used as input to FLEXPART-WRF. Several simulations showed computational particles passing over the receptor site, of which 6 are selected as transport episodes for a Lagrangian box model (LBM; SI Figures S1 and S2). The term transport episode is used here, for events with a significant (1.4-2.7\% of released computational particles i.e., 650-1000) large number of Lagrangian particles (trajectories) crossing the receptor box chosen for Finokalia. From the particle dump files, the computational particle positions and the interpolated meteorological parameters at these positions (e.g., humidity, temperature, mixed layer depth) were obtained using the Matlab software. FLEXPART-WRF was run with a gas tracer, so no chemical or physical degradation was simulated during transport, that is, the FLEXPART-WRF options for the reaction with $\mathrm{OH}$ radicals and dry and wet deposition were not used. Meteorological input data was produced with WRF version 3.4.1, for a spatial resolution of $3 \times 3 \mathrm{~km}^{2}$ and 36 vertical layers, (a nested domain, within a $9 \times 9 \mathrm{~km}^{2}$ mother domain) with $30 \mathrm{~min}$ temporal resolution. FLEXPART-WRF output was generated hourly. In all simulations, the number of particles released was equal to the number of seconds of the release time (the same as sampling duration at the source), this varied from 32400 to $49500(\approx 9-14 \mathrm{~h})$.

A LBM (hourly and $0.2^{\circ} \times 0.2^{\circ}$ resolutions, using the MATLAB software) was developed and used to simulate the chemical and physical degradation processes during the atmospheric transport from the source location (Urla) to the receptor site (Finokalia). For each of the 650-1000 computational particles per transport episode a box (parcel) of $1 \mathrm{~m}^{3}$ was defined. The particle coordinates and meteorological parameters $\left(T(K)\right.$, mixed layer depth $\left.\left(M_{L}, m\right)\right)$ of these computational particles were assigned to the LBM parcels. For clarification, in this paper, wherever the term "parcel" is used, this exclusively refers to the traveling LBM unit-volume boxes, while FLEXPART-WRF computational particles and collected 
PM are referred to using the term "particle". Within parcels the following processes are simulated: chemical degradation of PAHs, production and photolysis of NPAHs, gas-particle partitioning, stochastic dilution, revolatilization from the sea surface, and gas and particulate deposition. The NPAH concentration at the source site is assumed to be zero. This is justified as the NPAHs studied, 2NFLT and 2NPYR are not coemitted with PAHs in combustion processes, but exclusively formed in atmospheric chemistry (refs. 43, 64, 65, SI Table S1), and the air advected (from eastern and southeastern Europe) to the source site was very clean, that is, not or very little influenced by regional pollution. ${ }^{15}$ In the model, any possible PAH primary emissions along transport are neglected. This is justified regarding the very low population density on islands of the area and ship traffic: The population in this area is on the order of $1 \%$ of the population in the source area, Izmir. Ship counts suggests that depending on exact location of trajectory between the source and the receptor, emissions from $\leq 5$ ships (including ferries and small ships) could have influenced air parcels traveling in the marine boundary layer (Universal Shipborne Automatic Identification System, archived data, MarineTraffic, Oxford, UK, personal communication, 2019).

Besides the computational particle positions and the meteorological parameters provided by the FLEXPART$\mathrm{WRF}^{66}$ output, fields of relevant radicals, oxidants $\left(\mathrm{OH}, \mathrm{O}_{3}\right.$, $\mathrm{NO}_{2}$, and $\left.\mathrm{NO}_{3}\right)$ and fine particulate matter $\left(\mathrm{PM}_{2.5}\right)$ are further input of the LBM. The latter ones were taken from a simulation with the Eulerian Multiscale Atmospheric Transport and Chemistry model (MATCH $)^{67,68}$ at hourly and $0.2^{\circ}$ $\times 0.2^{\circ}$ resolutions and model levels $250,500,750,1000,1250$, 1500,2000 , and $3000 \mathrm{~m}$. The uncertainty of the oxidant (ozone and $\mathrm{NO}_{2}$ ) concentrations output by $\mathrm{MATCH}$ are expected to be $<15 \%$. ${ }^{69}$

The LBM (coded in MATLAB) consists of 7 modules i.e., (1) Read and preprocess FLEXPART-WRF output; (2) Read MATCH output; (3) Create stochastic dilution fields; (4) Assign oxidant concentrations to particle positions; (5) Generate ODE input parameters; (6) Run the ODE's; and (7) Postprocess output.

2.3.2. Integration of Ordinary Differential Equations. Because the LBM treats every released parcel as an individual Lagrangian traveling box, for each of these, at every hour of travel from the source to the receptor, ODEs are solved. The point source is the Urla site. The receptor box at Finokalia is horizontally defined by $35.13-35.33^{\circ} \mathrm{N}$ and $25.6-25.8^{\circ} \mathrm{E}$ (a larger one measuring $35.13-35.33^{\circ} \mathrm{N}$ and $25.4-26.0^{\circ} \mathrm{E}$ was also tested), and vertically by the mixing layer depth, as interpolated to particle positions by FLEXPART-WRF. Hence, this mixing layer depth varies per parcel and per hourly output. The ODE's (Euler forward) are as follows:

$$
\begin{aligned}
\mathrm{d} c_{\mathrm{NPAH}} / \mathrm{d} t= & k_{\mathrm{NPAH}} \times c_{\mathrm{ox}} \times\left(1-\theta_{\mathrm{PAH}}\right) \times c_{\mathrm{PAH}}-j_{5} \times \theta_{\mathrm{NPAH}} \times c_{\mathrm{NPAH}} \\
& -k_{\mathrm{dil}} \times \Delta c_{\mathrm{NPAH}} \\
\mathrm{d} c_{\mathrm{PAH}} / \mathrm{d} t= & F_{\text {sea_PAH }} / h_{\mathrm{fl}}-k_{\mathrm{gPAH}} \times c_{\mathrm{ox}} \times\left(1-\theta_{\mathrm{PAH}}\right) \times c_{\mathrm{PAH}} \\
& -k_{\mathrm{PPAH}} \times c_{\mathrm{ox}} \times \theta_{\mathrm{PAH}} \times c_{\mathrm{PAH}}-k_{\mathrm{dep} \_\mathrm{PAH}} \times \theta_{\mathrm{PAH}} \times c_{\mathrm{PAH}} \\
& -k_{\mathrm{dil}} \times \Delta c_{\mathrm{PAH}}
\end{aligned}
$$

Where $c_{\mathrm{PAH}}$ (molecules $\mathrm{cm}^{-3}$ ) is PAH concentration, initialized by the one observed at the Urla station, the $c_{o x}$ is the oxidant concentration taken from the MATCH model (molecules $\left.\mathrm{cm}^{-3}\right)$, the $k_{\mathrm{NPAH}}\left(\mathrm{cm}^{-3}\right.$ molec $\left.^{-1} \mathrm{~s}^{-1}\right)$ is the second order rate coefficient for chemical degradation of NPAHs in the gasphase, $j\left(\mathrm{~s}^{-1}\right)$ is the photolysis rate coefficient of NPAHs in the particulate phase, $\theta_{\mathrm{PAH}}$ and $\theta_{\mathrm{NPAH}}$ are the particulate mass fractions of the PAHs and NPAHs, respectively, $k_{\mathrm{dil}}\left(\mathrm{s}^{-1}\right)$ is the pseudoreaction rate coefficient for dilution in the traveling parcels, $\Delta c_{\mathrm{NPAH}}$ and $\Delta c_{\mathrm{NPAH}}$ are concentrations above background (see below, Section 2.3.5). $F_{\text {sea PAH }}$ (molecules $\mathrm{cm}^{-2} \mathrm{~s}^{-1}$ ) is the diffusive gas exchange flux with the sea surface (net of revolatilization and gaseous dry deposition), $h_{\mathrm{fl}}$ is the corresponding layer height, set to $30 \mathrm{~m}, k_{\mathrm{gPAH}}$ and $k_{\mathrm{pPAH}}\left(\mathrm{cm}^{-3}\right.$ molec $^{-1} \mathrm{~s}^{-1}$ ) are the first order rate coefficients for $\mathrm{PAH}$ degradation in the gas and particulate phases, respectively, and $k_{\text {dep РAH }}\left(s^{-1}\right)$ is the dry particulate deposition rate coefficient. Wet deposition is not considered, because no precipitation was recorded during the whole campaign. $F_{\text {sea_pAH, was derived }}$ from experimental data (at the receptor site) and found positive (volatilizational) for episodes 2-4. The flux was depositional for the other episodes. ${ }^{33}$

2.3.3. Atmospheric Chemistry. The chemical reactions of NPAHs are described as follows:

$$
\begin{aligned}
& \mathrm{PAH}_{\mathrm{g}}+\mathrm{OH} \rightleftharpoons \mathrm{PAHOH}_{\mathrm{g}} \\
& \mathrm{PAHOH}_{\mathrm{g}}+\mathrm{NO}_{2} \rightarrow \mathrm{NPAH} \\
& \mathrm{PAHOH}_{\mathrm{g}}+\mathrm{O}_{2} \rightarrow \text { products } \\
& \mathrm{PAH}_{\mathrm{g}}+\mathrm{NO}_{3} \rightleftharpoons \mathrm{NPAH} \\
& \mathrm{PAH}_{\mathrm{p} .}+\mathrm{O}_{3} \rightarrow \text { products } \\
& \mathrm{NPAH}_{\mathrm{p}}+\mathrm{h} \nu \rightarrow \text { products }
\end{aligned}
$$

with PAH standing for either FLT or PYR and indices $g$ and $p$ denoting gas and particulate phase species, respectively. After the rapid and reversible addition of $\mathrm{OH}$ to $\mathrm{PAH}$, the main NPAH-forming Reaction $\mathrm{R} 2 \mathrm{a}$ is only a minor pathway in the parallel reactions of the unstable $\mathrm{OH}$-adduct, $\mathrm{PAHOH}^{\bullet}$. The $\mathrm{OH}$-adduct may undergo three competing pathways: reaction with $\mathrm{NO}_{2}(\mathrm{R} 2 \mathrm{a})$, reaction with $\mathrm{O}_{2}(\mathrm{R} 2 \mathrm{~b})$ or decomposition back to the Reaction R1,-1. ${ }^{70}$ Reaction R3,-3 comprises two steps with reversible formation of the $\mathrm{NO}_{3}$-adduct in step 1 and reaction with $\mathrm{NO}_{2}$ in step $2 .^{70}$ The heterogeneous reaction of $\mathrm{PAH}_{\mathrm{p}}$ with $\mathrm{OH}$ is neglected in the scheme as it was found to not or negligibly contribute to NPAH formation in both field and laboratory studies. ${ }^{71,72}$ A heterogeneous direct nitration of $\mathrm{PAH}$ by $\mathrm{NO}_{2}$, possible in strong acidic phases, ${ }^{73}$ is neglected too, as no evidence has been found in field nor laboratory studies and its significance would be limited to ultrafine particles, if at all.

However, this chemistry, sustaining 2NFLT and 2NPYR is incompletely understood: experimental kinetic data for the NPAH gas-phase formation and photolysis rates are rather limited: For PAHs, data on Reaction R2a and R2b are available only for nitronaphthalenes and methylnitronaphthalenes. ${ }^{74-76}$ In laboratory experiments under high $\mathrm{NO}_{x}\left((4.8-48) \times 10^{13}\right.$ molecules $\left.\mathrm{cm}^{-3}\right)^{77}$ high NPAH/PAH yields were found, that is, $\approx 0.5 \%$ for $2 \mathrm{NPYR}$, and $3 \%$ during the day ( $\mathrm{OH}$ initiated) and $24 \%$ during the night $\left(\mathrm{NO}_{3}\right.$ initiated) for 2NFLT. These should be lower under ambient $\mathrm{NO}_{x}$ conditions $((0.5-50) \times$ $10^{10}$ molecules $\left.\mathrm{cm}^{-3}\right)$. In fact, values for the $\mathrm{NPAH} / \mathrm{PAH}$ ratios up to few percent have been observed: at the remote receptor site studied here, the time weighted mean 2NPAH/ PAH yields were 1.5 and $3.7 \%$ for PYR and FLT, respectively 
(Section 3.2, below), whereas in continental air in central Europe these were 0.6 and $4.1 \% .{ }^{15} \mathrm{NO}_{2}$ between the source and receptor site over the Aegean Sea ranged 0.2-2.0 ppbv (MATCH model, SI Table S5). In rural air in France $<0.01$ and $0.3 \%$ for 2 NPYR and 2NFLT, respectively, was found. ${ }^{13}$ In very clean air over the South Atlantic was found $<0.03$ and $1.9 \%$ for 2NPYR and 2NFLT, respectively (unpublished). In polluted atmospheres in summer, 1.2 and $1.7 \%$, were found on average for 2NPYR and 2NFLT, respectively (Athens, residential site), ${ }^{78} 0.6$ and $2.6 \%$, respectively (Marseille, urban site), ${ }^{13}$ and $\approx 0.1$ and $1.1 \%$, respectively (Grenoble, urban site).

Here, apart from current state of knowledge (default scheme), in order to account for data uncertainties, we test two more reactivity schemes. These represent findings from laboratory studies under unrealistically high $\mathrm{NO}_{x}$ conditions ${ }^{42,70}$ (empirical scheme), and an upper estimate with regard to NPAH abundance (upper estimate scheme). Reaction rates are listed in Table 1.

Default Reactivity Scheme. The $\mathrm{OH}$-adduct formed in Reaction $\mathrm{R} 1,-1$, reacts with rate limiting $\mathrm{NO}_{2}$ addition to form NPAH (R2a). (R2a) is in competition with degradation by $\mathrm{O}_{2}$ in an irreversible reaction pathway (R2b). Assuming steady state for the adduct concentration, $\mathrm{C}_{\mathrm{PAHOH}}$, it holds:

Table 1. FLT and PYR Chemistry Kinetic Data for $298 \mathrm{~K}$ Including Yield Expressions, $y_{\mathrm{OH}} \times k_{1}$ and $y_{\mathrm{NO} 3} \times k_{3}$, for 2NFLT and 2NPYR Formation Differing in Various Reactivity Schemes

\begin{tabular}{|c|c|c|c|}
\hline & scheme & $\begin{array}{l}\text { FLT or } \\
2 \text { NFLT }\end{array}$ & PYR or 2 NPYR \\
\hline $\begin{array}{l}\mathrm{y}_{\mathrm{OH}} \times k_{1}\left[10^{-12} \mathrm{~cm}^{3}\right. \\
\left.\text { molec }^{-1} \mathrm{~s}^{-1}\right]\end{array}$ & $\begin{array}{l}\text { default } \\
\text { empiric } \\
\text { upper }\end{array}$ & $\begin{array}{l}1 \times 11^{a} \\
0.03 \times 11^{a} \\
1 \times 11^{a}\end{array}$ & $\begin{array}{l}1 \times 50^{a} \\
0.005 \times 50^{a} \\
1 \times 50^{a}\end{array}$ \\
\hline$k_{2 \mathrm{a}}\left[10^{-12} \mathrm{~cm}^{3} \mathrm{molec}^{-1} \mathrm{~s}^{-1}\right]$ & $\begin{array}{l}\text { default } \\
\text { empiric } \\
\text { upper }\end{array}$ & $\begin{array}{l}0.36^{b} \\
\text { not applied } \\
373 \times \\
\quad 0.36^{b, c}\end{array}$ & $\begin{array}{l}0.36^{b} \\
\text { not applied } \\
373 \times 0.36^{b, c}\end{array}$ \\
\hline$k_{2 \mathrm{~b}}\left[10^{-17} \mathrm{~cm}^{3} \mathrm{molec}^{-1} \mathrm{~s}^{-1}\right]$ & $\begin{array}{l}\text { default } \\
\text { empiric } \\
\text { upper }\end{array}$ & $\begin{array}{l}1.0^{d} \\
\text { not applied } \\
1.0 / 373^{c, d}\end{array}$ & $\begin{array}{l}1.0^{d} \\
\text { not applied } \\
1.0 / 373^{c, d}\end{array}$ \\
\hline $\begin{array}{l}\mathrm{y}_{\mathrm{NO} 3} \times k_{3} \times\left|\mathrm{c}_{\mathrm{NO} 2}\right| \\
\quad\left[10^{-27} \mathrm{~cm}^{3} \mathrm{molec}^{-1} \mathrm{~s}^{-1}\right]\end{array}$ & $\begin{array}{l}\text { default } \\
\text { empiric }\end{array}$ & $\begin{array}{l}1 \times 0.51^{e} \\
0.24 \times \\
0.51^{e}\end{array}$ & $\begin{array}{l}1 \times 1.6^{e} \\
0 \times 0.51^{e}\end{array}$ \\
\hline$k_{4}\left[\mathrm{~s}^{-1}\right]$ & all & $0^{a}$ & $\begin{array}{l}7 \times 10^{-4} \mathrm{c}_{\mathrm{O} 3} / \\
\left(3 \times 10^{15}+\mathrm{c}_{\mathrm{O} 3}\right)^{f}\end{array}$ \\
\hline $\mathrm{j}_{5}\left[10^{-3} \mathrm{~s}^{-1}\right]$ & $\begin{array}{l}\text { default } \\
\text { empiric } \\
\text { upper }\end{array}$ & $\begin{array}{l}0.13^{g} \\
\text { not applied } \\
0.13^{g}\end{array}$ & $\begin{array}{l}0.13^{g, h} \\
\text { not applied } \\
0.13^{g, h}\end{array}$ \\
\hline
\end{tabular}

${ }^{a}$ Stands for the net process (Keyte et al., 2013; ${ }^{9}$ Finlayson-Pitts and Pitts, $\left.2002^{43}\right)$. ${ }^{b}$ Adopted from the reaction of the naphthalene-OH adduct with $\mathrm{NO}_{2}{ }^{84}{ }^{c}$ Enhancement factor 373 corresponding to the rate coefficient ratio $k_{2 \mathrm{a}} / k_{2 \mathrm{~b}}=5 \times 10^{9}$, predicted for PYR. ${ }^{83} d_{\text {Adopted }}$ from the reactions of the benzene $\mathrm{OH}$ adducts with $\mathrm{O}_{2}$ and its temperature dependence ${ }^{84-86}{ }^{e}$ Atkinson, $1991{ }^{87} f_{\text {Kahan }}$ et al.,

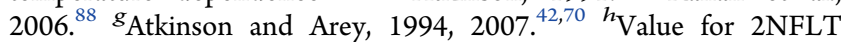
adopted as suggested by Fan et al., 1996. ${ }^{80}$

$$
k_{1}\left(1-\theta_{\mathrm{PAH}}\right) \times c_{\mathrm{PAH}} c_{\mathrm{OH}}=\left(k_{-1}+k_{2 \mathrm{a}} c_{\mathrm{NO} 2}+k_{2 \mathrm{~b}} c_{\mathrm{O} 2}\right) c_{\mathrm{PAHOH}} .
$$

where, $k_{-1}$ can be neglected since it is small against $k_{2 \mathrm{~b}} \mathrm{c}_{\mathrm{O} 2}$ in air at $1 \mathrm{~atm}$. The experimentally accessible $k_{1}$ (Table 1$)$ then stands for the net process of product formation $(\mathrm{R} 1,-1)$, and for the NPAH formation rate $\mathrm{d} c_{\mathrm{NPAH}} / \mathrm{d} t$ it holds:

$$
\mathrm{d} c_{\mathrm{NPAH}} / \mathrm{d} t=k_{2 \mathrm{a}} c_{\mathrm{NO} 2} c_{\mathrm{PAHOH}}+k_{3} \mathrm{c}_{\mathrm{NO} 3}\left(1-\theta_{\mathrm{PAH}}\right) \times c_{\mathrm{PAH}-j_{5}} \theta_{\mathrm{NPAH}} c_{\mathrm{NPAH}} .
$$

With $c_{\mathrm{PAHOH}}$ from 3 replaced in 4 , for the NPAH chemical source and sink (R5) terms this becomes

$$
\begin{aligned}
\mathrm{d} c_{\mathrm{NPAH}} / \mathrm{d} t= & k_{\mathrm{NPAH}} \times c_{\mathrm{PAH}}-j_{5} \times \theta_{\mathrm{NPAH}} \times c_{\mathrm{NPAH}} \\
= & {\left[k_{1} k_{2 \mathrm{a}} c_{\mathrm{NO} 2} c_{\mathrm{OH}} /\left(k_{2 \mathrm{a}} c_{\mathrm{NO} 2}+k_{2 b} c_{\mathrm{O} 2}\right)+k_{3} c_{\mathrm{NO} 3}\right] \times\left(1-\theta_{\mathrm{PAH}}\right) } \\
& \times c_{\mathrm{PAH}}-j_{5} \times \theta_{\mathrm{NPAH}} \times c_{\mathrm{NPAH}}
\end{aligned}
$$

The reaction rate coefficients of the OH-adducts of FLT and PYR, $k_{2 \mathrm{a}}$ and $k_{2 \mathrm{~b}}$, are adopted from data for benzene and naphthalene (as detailed in SI S2), because of lack of experimental data specifically for FLT and PYR. The ratio of rate coefficients of the reactions of the $\mathrm{OH}$-adduct with $\mathrm{NO}_{2}$ and $\mathrm{O}_{2}, k_{2 \mathrm{a}} / k_{2 \mathrm{~b}}$, has the value $3.6 \times 10^{4}$. For the NPAH sink term, a high estimate of $j_{5}$ (i.e., $1.3 \times 10^{-4} \mathrm{~s}^{-1}$ corresponding to noon) is adopted: A very high value, $5.0 \times 10^{-4} \mathrm{~s}^{-1}$, had been reported from reactivity on wood smoke particles. ${ }^{80}$ The relevant aerosol is certainly less reactive than wood smoke particles. Between 10 and $100 \%$ of $5.0 \times 10^{-4} \mathrm{~s}^{-1}$ was estimated on other aerosol surfaces. ${ }^{81}$ Good agreement between predicted and observed 2NFLT lifetime was found when assuming $j_{5}(2 \mathrm{NFLT})=j_{5}(2 \mathrm{NNAP}) \approx 1.3 \times 10^{-4} \mathrm{~s}^{-1} .42$

Heterogeneous oxidation reactions of PAHs as source of NPAHs are neglected, as these are considered to be far less significant in ambient air. ${ }^{42,82}$

$\mathrm{PAH}$ loss by ozone is considered in the particulate phase only, as the homogeneous reaction is considered to be negligible. 9,43

For the ODE for $\mathrm{c}_{\mathrm{PAH}}$, the default scheme contains the following equation:

$$
\begin{aligned}
\mathrm{d} c_{\mathrm{PAH}} / \mathrm{d} t= & {\left[k_{1} k_{2 \mathrm{a}} c_{\mathrm{NO} 2} c_{\mathrm{OH}} /\left(k_{2 \mathrm{a}} c_{\mathrm{NO} 2}+\mathrm{k}_{2 \mathrm{~b}} c_{\mathrm{O} 2}\right)+k_{3} c_{\mathrm{NO} 3}\right] \times\left(1-\theta_{\mathrm{PAH}}\right) } \\
& \times c_{\mathrm{PAH}}-\left[k_{4} c_{\mathrm{O} 3}\right] \times \theta_{\mathrm{PAH}} \times c_{\mathrm{PAH}}
\end{aligned}
$$

Empiric Reactivity Scheme. To the NPAH source term, $k_{\mathrm{NPAH}} \times c_{\mathrm{PAH}}$, the $2 \mathrm{NPAH} / \mathrm{PAH}$ yields which were observed in the laboratory under high $\mathrm{NO}_{x}$ conditions and light were applied. These were found to not extrapolate to zero for low $\mathrm{NO}_{x}$ conditions, which raises some confidence that they might be applicable under ambient conditions: ${ }^{42}$

$$
\mathrm{d} c_{\mathrm{NPAH}} / \mathrm{d} t=k_{\mathrm{NPAH}} \times c_{\mathrm{PAH}}=\left(k_{1} y_{\mathrm{OH}} c_{\mathrm{OH}}+k_{3} y_{\mathrm{NO} 3} c_{\mathrm{NO} 3}\right) \times c_{\mathrm{PAH}}
$$

with $y_{\mathrm{OH}}$ and $y_{\mathrm{NO} 3}$ being the respective yields, $c_{2 \mathrm{NPAH}} / c_{\mathrm{PAH}}$.

Note that these yields reported are not consistent with the above mechanism: the yields according to this mechanism would be given by $k_{2 \mathrm{a}} c_{\mathrm{NO} 2} /\left(\begin{array}{lll}k_{2 \mathrm{a}} & c_{\mathrm{NO} 2}+k_{2 \mathrm{~b}} & c_{\mathrm{O} 2}\end{array}\right)$, which corresponds to $0.003-0.3 \%$ for the ambient relevant range of $(1.2-120) \times 10^{10}$ molecules $\mathrm{cm}^{-3}(\approx 0.5-50 \mathrm{ppbv}) \mathrm{NO}_{2}$. In contrast, Atkinson and Arey, ${ }^{42}$ found independence of the $\mathrm{NPAH}$ yields of $c_{\mathrm{NO} 2}$. Consistent with the laboratory data, the photolysis sink term is not explicitly included in this empiric reactivity scheme. At least the yield for the oxidation by $\mathrm{OH}$ was observed in the presence of UV light $(<400 \mathrm{~nm}),{ }^{41}$ hence, at least a significant fraction of $j_{5}$ was included and sustained the yield observed. 
Upper Estimate Reactivity Scheme. The upper estimate of chemically sustained NPAH concentration deviates in $k_{2 \mathrm{a}}$ and $k_{2 \mathrm{~b}}$ from the default scheme: A higher value for the ratio $k_{2 \mathrm{a}} / k_{2 \mathrm{~b}}$ is chosen, $5 \times 10^{9}$, which had been predicted for PYR, ${ }^{83}$ related to the larger, 4-ring aromatic system. The value of $k_{2 \mathrm{a}} /$ $k_{2 \mathrm{~b}}$ obtained from experimental data, $3.6 \times 10^{4}$ for aromatics with $1-2$ rings, is in agreement with theoretical predictions $(9$ $\times 10^{3}$ and $8 \times 10^{4}$ for the benzene and naphthalene adducts, respectively. ${ }^{83}$ Because of delocalization over larger aromatic systems favoring the stability of the adduct and preferential interaction with the radical $\mathrm{NO}_{2}$. That is, combination of two radicals, $k_{2 \mathrm{a}} / k_{2 \mathrm{~b}}$ should be considerably higher for the $\mathrm{OH}$ adduct of PAHs with more rings. In this chemical reactivity scheme of high reactivity toward NPAH formation, $k_{2 a}$ is increased and $k_{2 \mathrm{~b}}$ is reduced such as the ratio $k_{2 \mathrm{a}} / k_{2 \mathrm{~b}}$ equals the theoretically predicted value for PYR, that is, $5 \times 10^{9} .{ }^{83}$ This is applied for both PYR and FLT as no such theoretical prediction is available for FLT.

$k_{1}$ is set to zero from 21:00 to 5:00 EEST $($ EET+1 $=$ UTC +3 ) and $k_{3}$ from 5:00 to 21:00 EEST. For every parcel, the concentrations of $\mathrm{OH}, \mathrm{NO}_{2}, \mathrm{NO}_{3}$, and $\mathrm{O}_{3}$ are obtained from $\mathrm{MATCH}$, from the grid cell corresponding to the parcel's location. For each air parcel, PAH degradation and NPAH formation are simulated by numerical integration of first order differential equations (using the ODE45 solver in the MATLAB software).

2.3.4. Gas-Particle Partitioning and Particulate Phase Deposition. The particulate fraction can be estimated as

$$
\theta=K_{\mathrm{P}} \times \mathrm{TSP} /\left(K_{\mathrm{P}} \times \mathrm{TSP}+1\right)
$$

with particle-gas partition coefficient, $K_{\mathrm{p}}\left(\mathrm{m}^{3} \mu \mathrm{g}^{-1}\right)$, and total suspended particulates' concentration $\left(\mathrm{m}^{3} \mu \mathrm{g}^{-1}\right)$. For the latter, the $\mathrm{PM}_{2.5}\left(\mu \mathrm{g} \mathrm{m}^{-3}\right)$ levels provided by the MATCH model were 'extrapolated' to $\mathrm{PM}_{10}$ (subsequently used as TSP) by using the observed ratio $\left(\mathrm{PM}_{10} / \mathrm{PM}_{2.5}\right)$ at Finokalia, as follows:

$$
\mathrm{TSP}_{\text {parcel }}=\mathrm{PM}_{10 \text { parcel }}=\mathrm{PM}_{2.5 \_\mathrm{MATCH}} \times\left(\mathrm{PM}_{10} / \mathrm{PM}_{2.5}\right)
$$

For PAHs the dual OM absorption and BC adsorption model $^{30}$ is applied:

$$
\begin{aligned}
K_{\mathrm{p}}= & 10^{-12}\left(f_{\mathrm{OM}} / \rho_{\mathrm{oct}} \times K_{\mathrm{OA}}+f_{\mathrm{BC}} / \rho_{\mathrm{BC}} \times K_{\text {soot-air }}\right. \\
& \left.\times a_{\mathrm{atm}-\mathrm{BC}} / a_{\text {soot }}\right)
\end{aligned}
$$

with the fraction of organic matter $f_{\mathrm{OM}}$ derived from the observed fraction of organic carbon $\mathrm{f}_{\mathrm{OC}}$ at Urla (ranging 0.570.8 , see SI Table S2), $f_{\mathrm{OM}}=f_{\mathrm{OC}} / 0.6$, the density of octanol, $\rho_{\text {oct }}$ is $0.820 \mathrm{~kg} \mathrm{~L}^{-1}$, black carbon (BC) properties are approximated by diesel soot, that is, a density of $1 \mathrm{~kg} \mathrm{~L}^{-1}$, for example, ${ }^{89} f_{\mathrm{BC}}$ was observed in Urla (ranging: 0.01-0.09, see SI Table S2), $a_{\mathrm{atm}-\mathrm{BC}} / a_{\text {soot }}$ is assumed to be $1 . K_{\mathrm{OA}}(\mathrm{T})$ is given as $\log K_{\mathrm{OA}}=-4.56+3985 / \mathrm{T}$ and $\log K_{\mathrm{OA}}=-4.34+3904 / \mathrm{T}$ for PYR and FLT, respectively. ${ }^{90} K_{\text {soot-air }}\left(P_{\mathrm{L}}\right)$ is given as

$$
\log K_{\text {soot-air }}\left[\mathrm{m}^{3} \mu \mathrm{g}^{-1}\right]=-0.85 \times \log P_{\mathrm{L}}[\mathrm{Pa}]-3.06-\log \left(998 / a_{\text {soot }}\right)
$$

following, ${ }^{91}$ with $\log P_{\mathrm{L}}(\mathrm{Pa})=11.70-4164 / \mathrm{T}$ and $\log P_{\mathrm{L}}(\mathrm{Pa})$ $=12.47-4382 / \mathrm{T}$ for PYR and FLT, respectively. ${ }^{90,92}$

For NPAHs, the particulate fraction, $\varphi_{\mathrm{NPAH}}$, is calculated from the observed concentrations in both phases at Finokalia (SI Table S3b). For each transport episode, one value of $\varphi_{\mathrm{NPAH}}$ is used for all time steps along transport to Finokalia. The inherent uncertainties are expected to not be larger than when predicting $\theta_{\mathrm{NPAH}}$ based on a gas-particle partitioning model, see ref 78 , because the model input parameters would be uncertain (estimates) and the temperature change during transport was small (ranged 282-306 K, 5-95\% ranged 292$303 \mathrm{~K})$.

The particulate phase deposition flux is defined as follows:

$$
F_{\text {dep }}=v_{\text {dep }} \times h_{\text {mix }}
$$

with $v_{\text {dep }}$ from, ${ }^{94}$ following. ${ }^{95}$ The mean wind speed $\left(5.4 \mathrm{~m} \mathrm{~s}^{-1}\right.$ based on 30 min averages; see also, ${ }^{33}$ was used to read the $v_{\text {dep }}$ from this literature source. ${ }^{94}$

2.3.5. Air-Sea Gas Exchange Flux and Stochastic Dilution Rate. According to gradient and micrometeorological measurements during the same campaign, ${ }^{33}$ in the model, the diffusive gas exchange flux with the sea surface, $F_{\text {sea }}\left(\mathrm{ng} \mathrm{m}^{-3} \mathrm{~h}^{-1}\right)$, that is, volatilization and gaseous dry deposition, is only accounted for parcels traveling over sea, below a reference height $\left(h_{\text {ref }}=\right.$ $30 \mathrm{~m}$ ) and during day-time. No volatilization during night time had been observed. ${ }^{3}$

The dispersion in the FLEXPART model dilutes the cloud of released particles. According to the definition of a Lagrangian model, inside a particle no dispersion or dilution occurs. However, when simulating concentration changes (of $\left.c_{\mathrm{PAH}}, c_{\mathrm{NPAH}}\right)$ in traveling volumes, dilution needs to be applied within these parcels. Similar to budgeting in a puff model, for example, ${ }^{96,97}$ where mass is conserved, while the volume expands, here the loss of mass is simulated and the volume kept constant $\left(1 \mathrm{~m}^{3}\right)$. Dilution is approximated as a first order pseudochemical reaction, recalculated for each time step

$$
\begin{aligned}
& \mathrm{d} N / \mathrm{d} t=-k_{\mathrm{dil}} \times N \\
& k_{\mathrm{dil}}=-\ln \left(N_{\mathrm{t}} / N_{t-1}\right) / 3600
\end{aligned}
$$

with $k_{\text {dil }}$ the pseudo reaction rate coefficient. $N$, the number of particles per grid cell, is taken from a pregenerated gridded field $\left(0.1^{\circ} \times 0.1^{\circ} ; 45\right.$ vertical levels between the surface and $4500 \mathrm{~m}$ ). In order to exclude extremes, the median over the $k_{\mathrm{dil}}$ within a release group is assigned to all parcels in that release group. A release group consists of the number of selected computational particles released in $1 \mathrm{~h}$ by FLEXPART-WRF. The $k_{\text {dil }}$ is only calculated for the computational particles that arrive in the receptor box, because only these are selected for the LBM. However, the positions of the total number of released particles per sample is used to obtain $N$, the number of particles per high resolution grid cell. In other words, if a release group is considered a puff, the median dilution over parcels per hour in a puff is allocated to all parcels in that puff. This can be justified for the homogeneous air flows and rather narrow plumes (see SI Figure S1). The terms $-k_{\text {dil }} \times \Delta c_{\mathrm{PAH}}$ and $-k_{\text {dil }} \times \Delta c_{\mathrm{NPAH}}$ are, accordingly, added to the ODEs eqs 1 and 2 , respectively. Hereby, $\Delta c$ refers to the concentration above background concentration, $c_{\text {bkcgrd }}$. $c_{\text {bkcgrd }}$ for PAHs is represented by the campaign mean total (gas + particulate) concentration at the remote receptor site. For NPAHs a zero background concentration is assumed.

\section{RESULTS AND DISCUSSION}

3.1. Lagrangian Transport Analyses. The large scale circulation was almost ideally suitable for the transport analysis: The synoptic situation during 2-11 July 2012 over the Aegean region caused a homogeneous air flow from Western Turkey to Crete. The sky was cloud-free all the time. 
a)
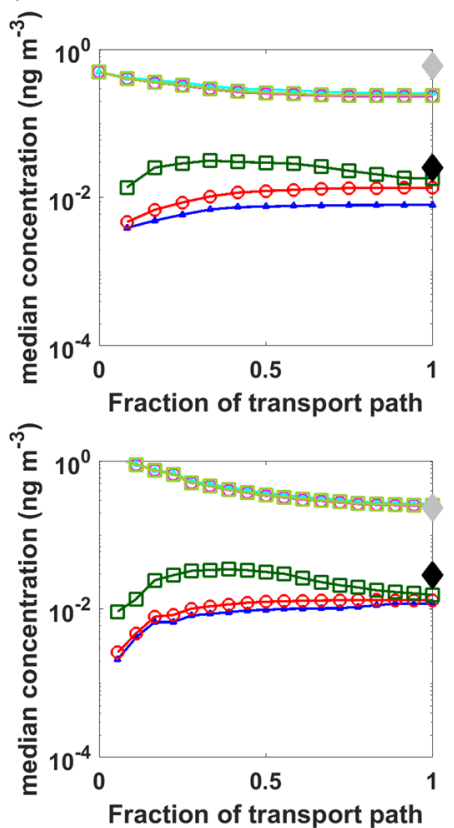

b)
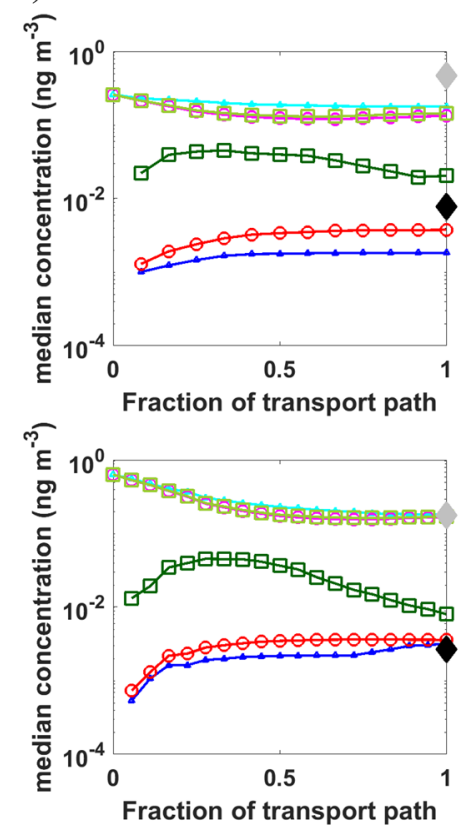
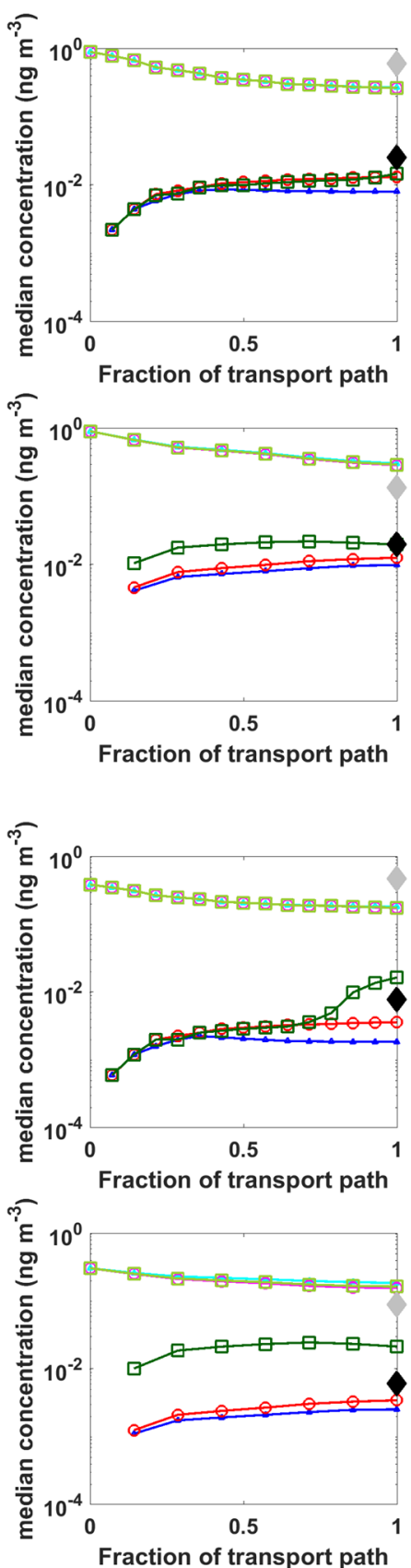
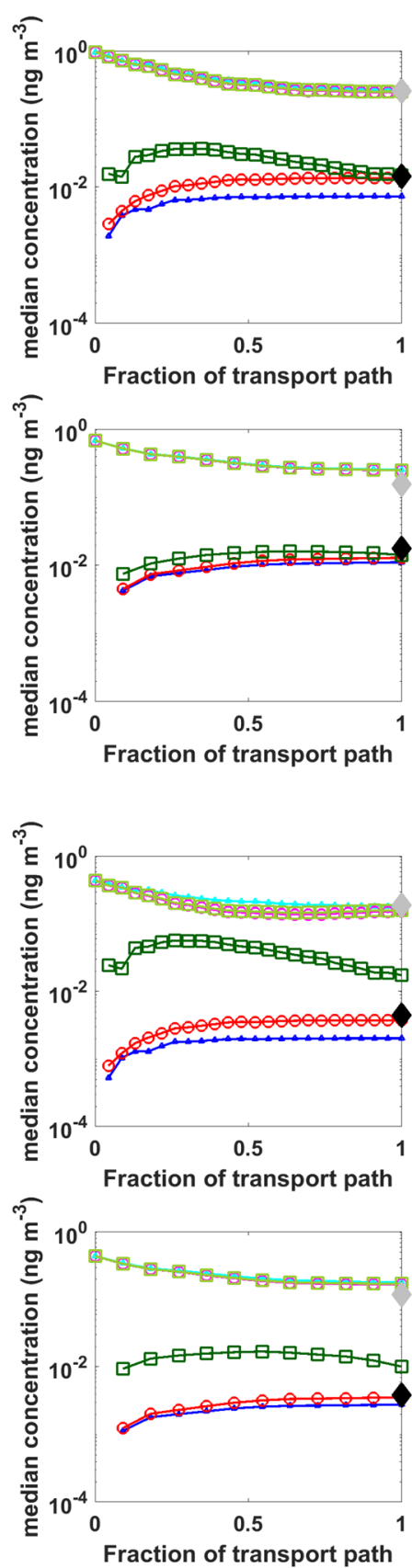

Figure 1. Change of predicted concentrations of PAH and NPAH (median of parcels followed, $\mathrm{ng} \mathrm{m}^{-3}$ ) for the selected transport episodes from source (Urla) to receptor (Finokalia) (first row episodes No. 1-3, second row episodes No. 4-6), and comparison with observed values (PAH: silver, NPAH: black) at the receptor site, for (a) FLT and (b) PYR, for default (PAH: light blue, NPAH: dark blue), empiric (PAH: pink, NPAH; red) and upper (PAH: light green, NPAH; dark green) reactivity schemes. Symbols along full lines mark full hours of transport time.

No frontal passage occurred, hence for all transport episodes homogeneous air mass transport could be assumed (SI Figure $\mathrm{S} 1)$. The urban influence from the source area, Izmir, as well as other urban areas in the region, on individual samples collected at the remote receptor site is quantified in SI Figure S3. ${ }^{15}$

SI Figures S1 and S2 illustrate the dispersion occurring as air pollution is transported from Urla to Finokalia. A few percent of the released particles in FLEXPART-WRF arrive directly in the receptor box. When a larger receptor box, tripled in eastwest direction $\left(35.13-35.33^{\circ} \mathrm{N} / 25.4-26.0^{\circ} \mathrm{E}\right.$, instead of $35.13-35.33^{\circ} \mathrm{N} / 25.6-25.8^{\circ} \mathrm{E}$ ) was tested, obviously more particles crossed the receptor box, while the predicted concentrations showed no significant changes. In order to compare the simulated concentrations upon arrival in the receptor box to the observed levels at Finokalia (in Figure 1 and SI Table S6), weighted means of several samples are necessary (cf. SI Table S4). SI Figure S2 shows the parcels belonging to the six selected Urla samples, and SI Table S4 how arrival times in the receptor box overlap with multiple sampling times at Finokalia.

3.2. PAH Transformation along Transport. The $\mathrm{PAH}$ and NPAH concentrations observed at the receptor site are listed in SI Table S3. These NPAH levels are by more than 1 order of magnitude lower than 1 decade before at the same site 
during the same season. ${ }^{15,16}$ The levels of NPAHs in the current study are the lowest ever reported from a marine environment.

The NPAH pattern observed, which includes primary (1NPYR) and secondary NPAHs (2NPYR, 2NFLT), confirms the perception of a receptor site, that is, that NPAHs were dominated by secondary formation (photochemistry, indicated by 2 NFLT $/ 1$ NPYR $>5$, this ratio actually ranged 7-21, see SI Table S3b). ${ }^{9}$ The $2 \mathrm{NPAH} / \mathrm{PAH}$ yields were $(3.7 \pm 0.2)$ and $(1.5 \pm 0.1) \%$ for FLT and PYR, respectively (time-weighted mean \pm standard deviation, $n=8$; SI Table S3b).

The matrix of samples collected at the source site (selected as episodes, marked bold in SI Table S2a) and samples collected at the receptor site (SI Table S3b), connected by transport are shown in SI Table S4. As in SI Figure S2, this matrix shows that arrival times in the receptor box overlap with multiple sampling times at Finokalia. Therefore, weighted means are calculated from the observed concentrations in order to compare the observed and simulated concentrations at the receptor site Finokalia. Figure 1 shows the PAH degradation and NPAH production during transport, as the median total concentration over all parcels per stage (or fraction) of travel. Per selected transport episode, the parcels per stage are determined by first finding the longest time it takes a parcel to reach the receptor, for example $20 \mathrm{~h}$; second, for all parcels the first value is placed at 1 and the last at 20 and the other values are equally distributed in between; and third, the missing values are interpolated. In this way, it is possible to visualize as median over all parcels per selected transport episode, how the concentration changes during different stages (fractions) of the travel. For example, the median PAH and NPAH concentrations at fraction 0.5 , is the median over the $\mathrm{PAH}$ and NPAH concentrations over all parcels when they are at $50 \%$ of the travel.

Predicted concentrations in same episode differed by up to a factor of $\approx 2$ across parcels (defined as the ratio between the $5 \%$ ile and $95 \%$ ile of the distribution). This mostly results from the spatial variation of the individual trajectories, and, hence, the spatial variability of LBM input, that is, most influential oxidant concentrations and meteorological parameters.

Episodes 1-3 contributed to one sample at the receptor site (F CG1; see SI Table S4). Because of the distribution of arrival times of samples (SI Table S4, most significant for episode 1), apparent underestimates of $\mathrm{PAH}$ and NPAH concentrations of this receptor site sample can be expected, and may explain up to a factor of 2-3. (In case of sample F_CG1, rather the sum of the predictions should be compared with the observation.) In our simulations, the ratio $2 \mathrm{NPAH} /$ $\mathrm{PAH}$ was assumed to be zero at the source site. However, an eventual NPAH background, formed in aged polluted air masses, could have been advected to the source site, thus leading to nonzero 2NPAH/PAH there, and apparent underestimate of NPAH levels at the receptor site. In fact, a small influence, $<2 \%$, of the Istanbul plume on the samples collected at the source site was indicated during episodes $1-4$ (samples F CG1-3 and F CG5) and episode 6 (in sample F_CG16; SI Figure S3, Table S43).

The simulations show that the available kinetic data (default reactivity scheme; SI Table S65, Figure 1, SI Figure S4) fail to explain observed NPAH formation, underestimating the NPAH concentration at the receptor site by typically 5 and 4 orders of magnitude for 2NFLT and 2NPYR, respectively. Under the empiric reactivity scheme, NPAH concentrations at the receptor site are still underestimated by $1-2$ orders of magnitude (SI Table S6, Figure 1 and SI Figure S4). For episodes 2-3, the 95th percentiles of the predictions are similar (FLT) or close (PYR) to the observed NPAH levels. This prediction was based on $y_{\mathrm{OH}}$ of 3.0 and $0.5 \%$ for $2 \mathrm{NFLT} /$ FLT and 2NPYR/PYR, respectively (Table 1). Even with the maximum yields observed in the field so far, that is, $4.1 \%$ and $1.5 \%$ for 2 NFLT/FLT (campaign mean in the South Atlantic, unpublished) and 2NPYR/PYR (this campaign mean) ${ }^{15}$ and, respectively, the discrepancy between predicted and observed would be of the same magnitude.

The predictions come closer to the observations under the upper reactivity scheme (SI Table S6, Figure 1 and SI Figure S4): 2 NFLT is underpredicted by 1 order of magnitude and 2NPYR is underestimated by a factor of 5-7 in episodes $1-2$ and a factor of $\approx 2$ in episodes $3-6$. The 95 th percentiles of the predictions exceed the observed NPAH levels by up to 1 order of magnitude, 2 NPYR in few episodes by more. Note that a significant part of the underestimate in episode 1 can be explained by the contribution of several episodes to the same sample (above). The medians of predicted yields range $0.2-$ $2.4 \%$ for 2 NFLT/FLT and $0.2-4.4 \%$ for 2 NPYR/PYR. The ranges of predicted $2 \mathrm{NFLT} / \mathrm{FLT}$ and $2 \mathrm{NPYR} / \mathrm{PYR}$ yields are in the same order of magnitude than observed at continental $^{13,15}$ and polluted sites, ${ }^{13,77,78}$ with the exception of predicted 2NPYR/PYR yields exceeding observations made in rural air in France ${ }^{13}$ and in very clean air over the South Atlantic (own unpublished data). No further comparison is possible, as reaction time is unknown for these observations. This upper reactivity scheme adopts a higher NPAH formation rate, dominated by a theoretically based (Density Functional Theory) ${ }^{83}$ and much higher ratio of rate coefficients, $k_{2 \mathrm{a}} / k_{2 \mathrm{~b}}$, for the 4-ring PAHs than for 1-2 ring PAHs.

We also tested the influence of the sink rate on NPAH prediction by switching off photolysis. This resulted in higher levels of NPAH, but not dramatically. Under a so modified upper reactivity scheme $\left(j_{5}=0\right.$, not in Table 1$), 2$ NFLT is still underpredicted by a factor of 3 in most episodes, while it matches quite well the observed value in episode 3 (data not shown), and 2NPYR predictions match quite well in episodes 1,5 , and 6 , and are found within 1 order of magnitude of discrepancy (underestimates as well as overestimates) in the other episodes. This clearly indicates, that it is the uncertainty of formation kinetics, not the uncertainty of the photolysis which is dominating the deficiency of the current kinetic knowledge (represented by the default reactivity scheme). The sink (photolysis, $j_{5}$ ) is particularly uncertain for PYR (value for FLT adopted, see Table 1). Field observations of very low ratios 2NPYR/PYR, that is, $<0.013 \%$ (rural France), ${ }^{13}<$ $0.03 \%$ (very clean air in the South Atlantic, unpublished) and $\approx 0.1$ (urban, Grenoble), ${ }^{79}$ suggest that $j_{5}$ for 2 NPYR might be lower than for 2NFLT.

Among the processes changing the $\mathrm{PAH}$ concentrations along transport, dilution ranks first ( $>50 \%$ for episodes No. $2-$ $6)$, and chemistry (empiric and upper reactivity schemes, episodes with day-times) or dry particle deposition (default reactivity scheme, and during night-time episodes of the other schemes) rank second (SI Figures S5 and S6). Chemistry ranks second when using the empiric or upper reactivity schemes, during episodes with day-times, while dry particle deposition ranks second when using the default reactivity scheme, as well as during the night-time episode (No. 2) when using the other schemes. Revolatilization is found to contribute negligibly 
$(<1 \%)$, regardless the scheme (SI Figures S5 and S6). This reflects the vertical distribution (altitude of traveling parcels) and significance of turbulence for mixing. The graphs for a mostly night-time transport episode (No. 2) using the empiric or upper reactivity scenarios, show that in the last few stages (fractions) the NPAH production increases caused by the degradation of the parent $\mathrm{PAHs}$ by $\mathrm{OH}$ after sunrise, which does not take place during the night. Dry particle deposition's significance for PAH sinks should be seen in the light of the particulate mass fractions i.e., 0.08 and 0.05 for FLT and PYR, respectively (mean values; SI Table S3b).

The PAH concentrations at the receptor site are mostly well predicted (Figure 1 and SI Figure S4), with the exception of episodes $1-2$. Again, as the episodes $1-3$ contributed to one sample at the receptor site, a large part of this discrepancy can be explained. Dispersion might also add to discrepancies between predicted and observed concentrations: In FLEXPART-WRF, the option was chosen to let FLEXPART-WRF internally calculate turbulent mixing using the planetary boundary layer height, Monin-Obukhov length, convective velocity scale, roughness length and friction velocity. This method is based on the presence of turbulent fluxes over land (especially the Monin-Obukhov Similarity Theory), when applied over sea, it is assumed to overestimate turbulence ${ }^{98}$ (and references therein). In this study, the FLEXPART-WRF model is applied on the regional scale. Hence, the dispersion could be overestimated, but not dramatically. This would imply an underestimation of the number of Lagrangian particles entering the receptor box. A more obvious effect is the possible overestimation of the pseudoreaction rate coefficient for dilution, $k_{\text {dil }}$ (described in Section 2.3.5), and thus underestimation of both PAH and NPAH concentrations.

OPAHs, coemitted with the parent PAHs and partly formed simultaneously with secondary NPAHs, may enhance NPAH photodegradation, as has been demonstrated by photolysis in cyclohexane solution, employing the Hammett equation to hydroxy- and oxyaromatics as cosolutes of 2NFLT and 2NPYR. ${ }^{99}$ The significance of such a process is not supported by our modeling, and cannot be assessed. More chemical processes and pathways are possibly relevant for NPAHs in a cloudy atmosphere, due to uptake and subsequent reactions in water droplets. ${ }^{93}$

In summary, the remaining uncertainties do not allow for an effective constraining of the chemistry. However, the modeling results are nevertheless conclusive, because a large discrepancy is found for NPAHs when the default reactivity scheme is used.

Atmospheric chemistry and transport during day and night in a cloud-free atmosphere was simulated by a Lagrangian box model, that is, a box model coupled to a Lagrangian particle dispersion model, FLEXPART-WRF, on a regional scale $(300-500 \mathrm{~km})$. The model covered transport over many hours up to 1 day. This model system is suitable to study any homogeneous or heterogeneous chemistry. For simulations of chemistry in a cloudy atmosphere and with precipitation events, respective phase equilibria and mass transfer processes would be needed to be included in the box model. This study focused on episodes during a homogeneous regional-scale flow from a source site to a remote environment. Regional Eulerian modeling of PAH chemistry would account for regional sources and flow patterns.

Three reactivity schemes were tested for the PAHs fluoranthene, and pyrene, and their derivatives 2-nitrofluoranthene and 2-nitropyrene, respectively. A Lagrangian box model was initialized with observations of PAHs from a source site and the results compared to observations of PAHs and NPAHs at a receptor site. The "default" reactivity scheme, representing the currently available kinetic data, underestimated the observations drastically. This discrepancy is dominated by a largely underestimated ratio of the rate coefficients of the $\mathrm{OH}$-adduct with $\mathrm{NO}_{2}$ and $\mathrm{O}_{2}, k_{2 \mathrm{a}} / k_{2 \mathrm{~b}}$, which must be higher for 4-ring PAHs. The reactivity scheme which uses a more realistic estimate of $k_{2 \mathrm{a}} / k_{2 \mathrm{~b}}$ can explain the observed NPAH level and yield. These kinetic data are needed to constrain the chemistry of NPAH formation in remote and polluted environment. This study suggests that the transformation of the pollutants FLT and PYR into their nitrated derivatives is efficient and significant on at least the regional scale. 2NFLT might indeed be ubiquitous.

Kinetic parameters of more reactions would be needed to be quantified in order to correctly predict the formation of the here studied NPAHs in the polluted environment (presence of photocatalysts) and cloudy atmosphere (aqueous phase chemistry). Similar kinetic data are needed to describe the nitration of other 2-4 ring parent PAHs covered in the field data set used here. ${ }^{15,32}$ Such data is urgently needed in order to quantify secondary NPAH sources, NPAH distribution in air and, ultimately, the contribution of these pollutants to inhalation exposure-related health risks.

\section{ASSOCIATED CONTENT}

\section{S Supporting Information}

The Supporting Information is available free of charge on the ACS Publications website at DOI: 10.1021/acs.est.9b03090.

Chemical analysis, chemical kinetic data, observational data, model input data, model output (PDF)

\section{AUTHOR INFORMATION}

\section{Corresponding Author}

*Phone: 42054949 4106; e-mail: gerhard.lammel@recetox. muni.cz.

ORCID

Gerhard Lammel: 0000-0003-2313-0628

\section{Present Address}

${ }^{\circ}$ General Dynamics Inc., Research Triangle Park, North Carolina, United States.

\section{Author Contributions}

G.L. conceived the study. C.E., G.L., R.P., A.S., and S.C.S. conducted the air sampling and field measurements. Y.D., P.K., P.P., and A.S. did the chemical analysis of samples. G.L. and M.D.M. did the field data analysis. G.L., J.W., and C.Z. compiled the reaction schemes. C.E., J.M., and M.D.M. prepared model input. G.L., M.D.M., and G.W. designed the Lagrangian box model. M.D.M. wrote the model and performed and analyzed the runs. G.L. and M.D.M. discussed the results and wrote the manuscript with input from all coauthors.

\section{Notes}

The authors declare no competing financial interest.

\section{ACKNOWLEDGMENTS}

We thank Jiři Kohoutek (MU) and Giorgos Kouvarakis (University of Crete) for on-site support, Gurdal Tuncel (Middle East Technical University) for EC analysis and Benjamin Bandowe (MPI) for discussions. This research was 
funded and received support from the Czech Science Foundation (P503 16-11537S), the Izmir Institute of Technology Research Fund (2013iYTE-14), the Max Planck Society and the European Union FP7 (262254, ACTRIS). The MU RECETOX Research Infrastructure was supported by the Czech Ministry of Education, Youth and Sports (LM2015051 and CZ.02.1.01/0.0/0.0/16_013/0001761).

\section{REFERENCES}

(1) WHO, World Health Organization. Health Risks of Persistent Organic Pollutants from Long-Range Transboundary Air Pollution; WHO Regional Office for Europe, Copenhagen, 2003.

(2) Hansen, T.; Seidel, A.; Borlak, J. The environmental carcinogen 3-nitrobenzanthrone and its main metabolite 3-aminobenzanthrone enhance formation of reactive oxygen intermediates in human A549 lung epithelial cells. Toxicol. Appl. Pharmacol. 2007, 221, 222-234.

(3) Park, E. J.; Park, K. Induction of pro-inflammatory signals by 1 nitropyrene. Toxicol. Lett. 2009, 184, 126-133.

(4) IARC, International Agency for Research on Cancer. In Diesel and Gasoline Engine Exhausts and Some Nitroarenes, IARC Monographs on the Evaluation of Carcinogenic Risks to Humans; Lyon, 2013; Vol. 105.

(5) Walsh, G. E. Toxic effects of pollutants on plankton. In Principles of Ecotoxicology; Butler, G. C., Ed.; Wiley: New York, pp 257-274.

(6) Gray, J. S. Biomagnification in marine systems: The perspective of an ecologist. Mar. Pollut. Bull. 2002, 45, 46-52.

(7) Lammel, G.; Sehili, A. M.; Bond, T. C.; Feichter, J.; Grassl, H. Gas/particle partitioning and global distribution of polycyclic aromatic hydrocarbons - a modelling approach. Chemosphere 2009, $76,98-106$.

(8) van Drooge, B. L.; Fernández, P.; Grimalt, J. O.; Stuchlík, E.; Torres García, C. J.; Cuevas, E. Atmospheric PAHs in remote European and Atlantic sites located above the boundary mixing layer. Environ. Sci. Pollut. Res. 2010, 17, 1207-1216.

(9) Keyte, I. J.; Harrison, R. M.; Lammel, G. Chemical reactivity and long-range transport potential of polycyclic aromatic hydrocarbons a review. Chem. Soc. Rev. 2013, 42, 9333-939.

(10) Friedman, C.; Zhang, Y. X.; Selin, N. Climate change and emission impacts on atmospheric polycyclic aromatic hydrocarbon transport to the Arctic. Environ. Sci. Technol. 2014, 48, 429-437.

(11) Ramdahl, T.; Zielinska, B.; Arey, J.; Atkinson, R.; Winer, A. M.; Pitts, J. N. Ubiquitous occurrence of 2-nitrofluoranthene and 2nitropyrene in air. Nature 1986, 321, 425-427.

(12) Ciccioli, P.; Cecinato, A.; Brancaleoni, E.; Frattoni, M.; Zacchei, P.; Miguel, A.; de Castro Vasconcellos, P. Formation and transport of 2-nitrofluoranthene and 2-nitropyrene of photochemical origin in the troposphere. J. Geophys. Res. 1996, 101, 19567-19582.

(13) Albinet, A.; Leoz-Garziandia, E.; Budzinski, H.; Villenave, E. Polycyclic aromatic hydrocarbons (PAHs), nitrated PAHs and oxygenated PAHs in ambient air of the Marseilles area (South of France): Concentrations and sources. Sci. Total Environ. 2007, 384, 280-292.

(14) Albinet, A.; Leoz-Garziandia, E.; Budzinski, H.; Villenave, E.; Jaffrezo, J. L. Nitrated and oxygenated derivatives of polycyclic aromatic hydrocarbons in the ambient air of two French alpine valleys part 1: concentrations, sources and gas/particle partitioning. Atmos. Environ. 2008, 42, 43-54.

(15) Lammel, G.; Mulder, M. D.; Shahpoury, P.; Kukučka, P.; Lišková, H.; Přibylová, P.; Prokeš, R.; Wotawa, G. Nitro-polycyclic aromatic hydrocarbons - gas-particle partitioning, mass size distribution, and formation along transport in marine and continental background air. Atmos. Chem. Phys. 2017, 17, 6257-6270.

(16) Tsapakis, M.; Stephanou, E. G. Diurnal cycle of PAHs, nitroPAHs and oxy-PAHs in a high oxidant capacity marine background atmosphere. Environ. Sci. Technol. 2007, 41, 8011-8017.

(17) Lohmann, R.; Klánová, J.; Př́bylová, P.; Lišková, H.; Yonis, S.; Bollinger, K. PAHs on an east-to-west transect across the tropical Atlantic Ocean. Environ. Sci. Technol. 2013, 47, 2570-2578.
(18) González-Gaya, B.; Fernández-Pinos, M. C.; Morales, L.; Méjanelle, L.; Abad, E.; Piña, B.; Duarte, C. M.; Jiménez, B.; Dachs, J. High atmosphere-ocean exchange of semivolatile aromatic hydrocarbons. Nat. Geosci. 2016, 9, 438-444.

(19) Halsall, C. J.; Barrie, L. A.; Fellin, P.; Muir, D. C. G.; Billeck, B. N.; Lockgart, L.; Rovinsky, F. Y.; Kononov, E. Y.; Pastukhov, B. Spatial and temporal variation of PAHs in the Arctic atmosphere. Environ. Sci. Technol. 1997, 31, 3593-3599.

(20) Vincenti, M.; Maurino, V.; Minero, C.; Pelizzetti, E. Determination of nitro-substituted polycyclic aromatic hydrocarbons in the Antarctic airborne particles. Int. J. Environ. Anal. Chem. 2001, 79, 257-272.

(21) Wang, L.; Na, G. S.; Ma, X. D.; Fang, X. D.; Ge, L. K.; Gao, H.; Yao, Z. W. Occurrence and gas-particle partitioning of polycyclic aromatic hydrocarbons in the atmosphere from the North Pacific to the Arctic Ocean. Atmos. Environ. 2013, 77, 640-646.

(22) Yaffe, D.; Cohen, Y.; Arey, J.; Grosovsky, A. J. Multimedia analysis of PAHs and nitro-PAH daughter products in the Los Angeles basin. Risk Anal. 2001, 21, 275-294.

(23) Siak, J.; Chan, T. L.; Gibson, T. L.; Wolff, G. T. Contribution to bacterial mutagenicity from nitro-PAH compounds in ambient aerosols. Atmos. Environ. 1985, 19, 369-376.

(24) Nitroarenes-Occurrence, metabolism, and biological impact. In Environmental Science Research; Howard, P. C., Hecht, S. S., Beland, F. A., Eds.; Plenum: New York, Vol. 40.

(25) Misaki, K.; Takamura-Enya, T.; Ogawa, H.; Takamori, K.; Yanagida, M. Tumour-promoting activity of polycyclic aromatic hydrocarbons and their oxygenated or nitrated derivatives. Mutagenesis 2016, 31, 205-213.

(26) Geier, M. C.; Chlebowski, A. C.; Truong, L.; Massey Simonich, S. L.; Anderson, K. A.; Tanguay, R. L. Comparative developmental toxicity of a comprehensive suite of polycyclic aromatic hydrocarbons. Arch. Toxicol. 2018, 92, 571-586.

(27) Andersson, H.; Piras, E.; Demma, J.; Hellman, B.; Brittebo, E. Low levels of the air pollutant 1-nitropyrene induce DNA damage, increased levels of reactive oxygen species and endoplasmic reticulum stress in human endothelial cells. Toxicology 2009, 262, 57-64.

(28) Øvrevik, J.; Arlt, V. M.; Øya, E.; Nagy, E.; M?llerup, S.; Phillips, D. H.; Låg, M.; Holme, J. A. Differential effects of nitro-PAHs and amino-PAHs on cytokine and chemokine responses in human bronchial epithelial BEAS-2B cells. Toxicol. Appl. Pharmacol. 2010, 242, 270-280.

(29) Bidleman, T. F. Atmospheric processes - wet and dry deposition of organic compounds are controlled by their vaporparticle partitioning. Environ. Sci. Technol. 1988, 22, 361-368.

(30) Lohmann, R.; Lammel, G. Adsorptive and absorptive contributions to the gas particle partitioning of polycyclic aromatic hydrocarbons: State of knowledge and recommended parameterisation for modelling. Environ. Sci. Technol. 2004, 38, 3793-3803.

(31) Guitart, C.; García-Flor, N.; Miguel, J. C.; Fowler, S. W.; Albaigés, J. Effects of accumulation of polycyclic aromatic hydrocarbons in the sea surface microlayer on their coastal air-sea exchange. J. Mar. Sys. 2010, 79, 210-217.

(32) Lammel, G.; Audy, O.; Besis, A.; Efstathiou, C.; Eleftheriadis, K.; Kohoutek, J.; Kukučka, P.; Mulder, M. D.; Přibylová, P.; Prokeš, R.; Rusina, T.; Samara, C.; Sofuoglu, A.; Sofuoglu, S. C.; Taşdemir, Y.; Vassilatou, V.; Voutsa, D.; Vrana, B. Air and seawater pollution and air-sea gas exchange of persistent toxic substances in the Aegean Sea: spatial trends of PAHs, PCBs, OCPs and PBDEs. Environ. Sci. Pollut. Res. 2015, 22, 11301-11313.

(33) Lammel, G.; Meixner, F. X.; Vrana, B.; Efstathiou, C.; Kohoutek, J.; Kukučka, P.; Mulder, M. D.; Přibylová, P.; Prokeš, R.; Rusina, T. S.; Song, G. Z.; Tsapakis, M. Bi-directional air-sea exchange and accumulation of POPs (PAHs, PCBs, OCPs and PBDEs) in the nocturnal marine boundary layer. Atmos. Chem. Phys. 2016, 16, 63816393.

(34) Cetin, B.; Yurdakul, S.; Keles, M.; Celik, I.; Öztürk, F.; Dogan, C. Atmospheric concentration distributions and air-soil exchange tendencies of polycyclic aromatic hydrocarbons and polychlorinated 
biphenyls in a heavily industrialized area in Koaceli, Turkey. Chemosphere 2017, 183, 69-79.

(35) Kwamena, N. O. A.; Stalkova, M. G.; Doaldson, D. J.; George, I. J.; Abbatt, J. P. D. Role of the aerosol substrate in the heterogeneous ozonation reactions of surface-bound polycyclic aromatic hydrocarbons. J. Phys. Chem. A 2007, 111, 11050-11058.

(36) Andersson, J. T.; Achten, C. Time to say goodbye to the 16 EPA PAHs? Toward an up-to-date use of PACs for environmental purposes. Polycyclic Aromat. Compd. 2015, 15, 330-354.

(37) Mu, Q.; Shiraiwa, M.; Octaviani, M.; Ma, N.; Ding, A. J.; Su, H.; Lammel, G.; Pöschl, U.; Cheng, Y. F. Temperature effect on phase state and reactivity controls atmospheric multiphase chemistry and transport of PAHs. Sci. Adv. 2018, 4, aap73148.

(38) Offenberg, J. H.; Baker, J. E. Precipitation scavenging of polychlorinated biphenyls and polycyclic aromatic hydrocarbons along an urban to over-water transect. Environ. Sci. Technol. 2002, 36, 3763-3771.

(39) Škrdlíková, L.; Landlová, L.; Klánová, J.; Lammel, G. Wet deposition and scavenging efficiency of gaseous and particulate phase polycyclic aromatic compounds at a central European suburban site. Atmos. Environ. 2011, 45, 4305-4312.

(40) Shahpoury, P.; Lammel, G.; Albinet, A.; Sofuoğlu, A.; Domanoğlu, Y.; Sofuoğlu, C. S.; Wagner, Z.; Ždimal, V. Evaluation of a conceptual model for gas-particle partitioning of polycyclic aromatic hydrocarbons using poly-parameter linear free energy relationships. Environ. Sci. Technol. 2016, 50, 12312-12319.

(41) Arey, J.; Zielinska, B.; Atkinson, R.; Winer, A. M.; Ramdahl, T.; Pitts, J. N. The formation of nitro-PAH from the gas-phase reactions of fluoranthene and pyrene with the $\mathrm{OH}$ radical in the presence of $\mathrm{NO}_{2}$. Atmos. Environ. 1986, 20, 2339-2345.

(42) Atkinson, R.; Arey, J. Atmospheric chemistry of polycyclic aromatic hydrocarbons: Formation of atmospheric mutagens. Environ. Health Persp. 1994, 102, 117-126.

(43) Finlayson-Pitts, B. J.; Pitts, J. N. Chemistry of the Upper and Lower Atmosphere: Theory, Experiments, Application; Academic Press: San Diego, CA, 2002.

(44) Reisen, F.; Arey, J. Atmospheric reactions influence seasonal $\mathrm{PAH}$ and nitro-PAH concentrations in the Los Angeles Basin. Environ. Sci. Technol. 2005, 39, 64-73.

(45) Pietrogrande, M. C.; Abbaszade, G.; Schnelle-Kreis, J.; Bacco, D.; Mercuriali, M.; Zimmermann, R. Seasonal variation and source estimation of organic compounds in urban aerosol of Augsburg, Germany. Environ. Pollut. 2011, 159, 1861-1868.

(46) Ringuet, J.; Albinet, A.; Leoz-Garziandia, E.; Budzinski, H.; Villenave, E. Diurnal/nocturnal concentrations and sources of particulate-bound PAHs, OPAHs and NPAHs at traffic and suburban sites in the region of Paris (France). Sci. Total Environ. 2005, 437, 297-305.

(47) Bandowe, B. A. M.; Meusel, H. Nitrated polycyclic aromatic hydrocarbons (nitro-PAHs) in the environment - a review. Sci. Total Environ. 2017, 581-582, 237-257.

(48) Aulinger, A.; Matthias, V.; Quante, M. Introducing a partitioning mechanism for PAHs into the Community Multiscale Air Quality Modeling System and its application to simulating the transport of benzo(a)pyrene over Europe. J. Appl. Meteor. Climatol. 2007, 46, 1718-1730.

(49) Zhang, Y. X.; Shen, H. Z.; Tao, S.; Ma, J. M. Modeling the atmospheric transport and outflow of polycyclic aromatic hydrocarbons emitted from China. Atmos. Environ. 2011, 45, 2820-2827.

(50) Inomata, Y.; Kajino, M.; Sato, K.; Ohara, T.; Kurokawa, J. I.; Ueda, H.; Tang, N.; Hayakawa, K.; Ohizumi, T.; Akimoto, H. Emission and atmospheric transport of particulate PAHs in Northeast Asia. Environ. Sci. Technol. 2012, 46, 4941-4949.

(51) Silibello, C.; Calori, G.; Costa, M. P.; Dirodi, M. G.; Mircea, M.; Radice, P.; Vitali, L.; Zanini, G. Benzo[a]pyrene modelling over Italy: comparison with experimental data and source apportionment. Atmos. Pollut. Res. 2012, 3, 399-407.
(52) Efstathiou, C. I.; Matejovičová, J.; Bieser, J.; Lammel, G. Evaluation of gas-particle partitioning in a regional air quality model for organic pollutants. Atmos. Chem. Phys. 2016, 16, 15327-15345.

(53) Prevedouros, K.; Jones, K. C.; Sweetman, A. J. Modelling the atmospheric fate and seasonality of polycyclic aromatic hydrocarbons in the UK. Chemosphere 2004, 56, 195-208.

(54) Sehili, A. M.; Lammel, G. Global fate and distribution of polycyclic aromatic hydrocarbons emitted from Europe and Russia. Atmos. Environ. 2000, 41, 8301-8315.

(55) Galarneau, E.; Makar, P. A.; Zheng, Q.; Narayan, J.; Zhang, J.; Moran, M. D.; Bari, M. A.; Pathela, S.; Chen, A.; Chlumsky, R. PAH concentrations simulated with the AURAMSPAH chemical transport model over Canada and the USA. Atmos. Chem. Phys. 2014, 14, 4065-4077.

(56) Whaley, C. H.; Galarneau, E.; Makar, P. A.; Akingunola, A.; Gong, W. M.; Gravel, S.; Moran, M. D.; Stroud, C.; Zhang, J. H.; Zheng, Q. GEM-MACH-PAH (rev2488): a new high-resolution chemical transport model for North American polycyclic aromatic hydrocarbons and benzene. Geosci. Model Dev. 2018, 11, 2609-2632.

(57) Arey, J.: Atmospheric reactions of PAHs including formation of nitroarenes. In: PAHs and related compounds. In Handbook of Environmental Chemistry; Neilson, A. N., Ed.; Springer: Cham, Switzerland, 1998; Vol. 3I, pp 347-385.

(58) RAIS, The Risk Assessment Information System: Toxicity profiles, RAIS, Oak Ridge National Laboratory, Oak Ridge, USA, internet: https://rais.ornl.gov/tox/profiles (accessed 30 September 2018).

(59) Tsapakis, M.; Stephanou, E. G. Polycyclic aromatic hydrocarbons in the atmosphere of the Eastern Mediterranean. Environ. Sci. Technol. 2005, 39, 6584-6590.

(60) Castro-Jiménez, J.; Berrojalbiz, N.; Wollgast, J.; Dachs, J. Polycyclic aromatic hydrocarbons (PAHs) in the Mediterranean Sea: atmospheric occurrence, deposition and decoupling with settling fluxes in the water column. Environ. Pollut. 2012, 166, 40-47.

(61) Mulder, M. D.; Heil, A.; Kukučka, P.; Kuta, J.; Přibylová, P.; Prokeš, R.; Lammel, G. Long-range atmospheric transport of PAHs, PCBs, OCPs and PBDEs to the central and eastern Mediterranean in summer 2010. Atmos. Environ. 2015, 111, 51-59.

(62) Mihalopoulos, N.; Stephanou, E.; Kanakidou, M.; Pilitsidis, S.; Bousquet, P. Tropospheric aerosol ionic composition in the Eastern Mediterranean region. Tellus, Ser. B 1997, 49, 314-326.

(63) Kouvarakis, G.; Tsigaridis, K.; Kanakidou, M.; Mihalopoulos, $\mathrm{N}$. Temporal variations of surface regional background ozone over Crete Island in the southeast Mediterranean. J. Geophys. Res. 2000, $105,4399-4407$.

(64) Bamford, H. A.; Bezabeh, D. Z.; Schantz, M. M.; Wise, S. A.; Baker, J. E. Determination and comparison of nitrated-polycyclic aromatic hydrocarbons measured in air and diesel particulate reference materials. Chemosphere 2003, 50, 575-587.

(65) Zimmermann, K.; Jariyasopit, N.; Massey Simonich, S. L.; Tao, S.; Atkinson, R.; Arey, J. Formation of nitro-PAHs from the heterogeneous reaction of ambient particle-bound PAHs with $\mathrm{N}_{2} \mathrm{O}_{5} / \mathrm{NO}_{3} / \mathrm{NO}_{2}$. Environ. Sci. Technol. 2013, 47, 8434-8442.

(66) Brioude, J.; Arnold, D.; Stohl, A.; Cassiani, M.; Morton, D.; Seibert, P.; Angevine, W.; Evan, S.; Dingwell, A.; Fast, J. D.; Easter, R. C.; Pisso, I.; Burkhart, J.; Wotawa, G. The Lagrangian particle dispersion model FLEXPART-WRF version 3.1. Geosci. Model Dev. 2013, 6, 1889-1904. 2013.

(67) Robertson, L.; Langner, J.; Engardt, M. An Eulerian limited area atmospheric transport model. J. Appl. Met. 1999, 38, 190-210.

(68) Andersson, C.; Bergström, R.; Bennet, C.; Robertson, L.; Thomas, M.; Korhonen, H.; Lehtinen, K. E. J.; Kokkola, H. MATCHSALSA - Multi-scale atmospheric transport and chemistry model coupled to the SALSA aerosol microphysics model - Part 1: Model description and evaluation. Geosci. Model Dev. 2015, 8, 171189.

(69) Andersson, C.; Langner, J.; Bergström, R. Interannual variation and trends in air pollution over Europe due to climate variability 
during 1958-2001 simulated with a regional CTM coupled to the ERA40 reanalysis. Tellus, Ser. B 2007, 59, 77-98.

(70) Atkinson, R.; Arey, J. Mechanisms of the gas-phase reactions of aromatic hydrocarbons and PAHs with $\mathrm{OH}$ and $\mathrm{NO}_{3}$ radicals. Polycyclic Aromat. Compd. 2007, 27, 15-40.

(71) Dimashki, M.; Harrad, S.; Harrison, R. M. Measurements of nitro-PAH in the atmospheres of two cities. Atmos. Environ. 2000, 34, $2459-2469$.

(72) Jariyasopit, N.; Zimmermann, K.; Schrlau, J.; Arey, J.; Atkinson, R.; Yu, T. W.; Dashwood, R. H.; Tao, S.; Massey Simonich, S. L. Heterogeneous reactions of particulate matter-bound PAHs and NPAHs with $\mathrm{NO}_{3} / \mathrm{N}_{2} \mathrm{O}_{5}$, OH Radicals, and $\mathrm{O} 3$ under simulated longrange atmospheric transport conditions: Reactivity and mutagenicity. Environ. Sci. Technol. 2014, 48, 10155-10164.

(73) Ruehle, P. H.; Bosch, L. C.; Duncan, W. P. Synthesis of nitrated polycyclic aromatic hydrocarbons. In Nitrated Polycyclic Hydrocarbons; White, C. M., Ed.; Hüthig: Heidelberg, Germany, pp169-235, 1985.

(74) Phousongphouang, P. T.; Arey, J. Rate constants for the photolysis of the nitronaphthalenes and methylnitronaphthalenes. $J$. Photochem. Photobiol., A 2003, 157, 301-309.

(75) Nishino, N.; Atkinson, R.; Arey, J. Formation of nitro products from the gas-phase $\mathrm{OH}$ radical-initiated reactions of toluene, naphthalene, and biphenyl: effect of $\mathrm{NO}_{2}$ concentration. Environ. Sci. Technol. 2008, 42, 9203-9209.

(76) Nishino, N.; Arey, J.; Atkinson, R. 2-Formylcinnamaldehyde formation yield from the $\mathrm{OH}$ radical-initiated reaction of naphthalene: Effect of $\mathrm{NO}_{2}$ concentration. Environ. Sci. Technol. 2012, 46, 81988204. 2012

(77) Atkinson, R.; Arey, J.; Zielinska, B.; Aschmann, S. M. Kinetics and nitro-products of the gas-phase $\mathrm{OH}$ and $\mathrm{NO}_{3}$ radical-initiated reactions of naphthalene-d, fluoranthene-d10, and pyrene. Int. J. Chem. Kinet. 1990, 22, 999-1014.

(78) Marino, F.; Cecinato, A.; Siskos, P. A. Nitro-PAH in ambient particulate matter in the atmosphere of Athens. Chemosphere 2000, 40, 533-537.

(79) Tomaz, S.; Shahpoury, P.; Jaffrezo, J. L.; Lammel, G.; Perraudin, E.; Villenave, E.; Albinet, A. One year study of polycyclic aromatic compounds at an urban site in Grenoble (France): seasonal variations, gas/particle partitioning and cancer risk estimation. Sci. Total Environ. 2016, 565, 1071-1083.

(80) Fan, Z. H.; Kamens, R. M.; Hu, J. X.; Zhang, J. B.; McDow, S. Photostability of nitro-polycyclic aromatic hydrocarbons on combustion soot particles in sunlight. Environ. Sci. Technol. 1996, 30, 13581364.

(81) García-Berríos, Z. I.; Arce, R. Photodegradation mechanisms of 1-nitropyrene, an environmental pollutant: The effect of organic solvents, water, oxygen, phenols, and polycyclic aromatics on the destruction and product yields. J. Phys. Chem. A 2012, 116, 36533664.

(82) Zimmermann, K.; Jariyasopit, N.; Massey Simonich, S. L.; Tao, S.; Atkinson, R.; Arey, J. Formation of nitro-PAHs from the heterogeneous reaction of ambient particle-bound PAHs with $\mathrm{N}_{2} \mathrm{O}_{5} / \mathrm{NO}_{3} / \mathrm{NO}_{2}$. Environ. Sci. Technol. 2013, 47, 8434-8442.

(83) Ghigo, G.; Causá, M.; Maranzana, A.; Tonachini, G. Aromatic hydrocarbon nitration under tropospheric and combustion conditions. A theoretical mechanistic study. J. Phys. Chem. A 2006, 110, 13270-13282.

(84) Feilberg, A.; Kamens, R.; Strommen, M. R.; Nielsen, T. Modeling the formation, decay and partitioning of semivolatile nitroPAH (nitronaphthalenes) in the atmosphere. Atmos. Environ. 1999, 33, 1231-1243.

(85) Knispel, R.; Koch, R.; Siese, M.; Zetzsch, C. Adduct formation of $\mathrm{OH}$ radicals with benzene, toluene, and phenol and consecutive reactions of the adducts with $\mathrm{NO}_{\mathrm{x}}$ and $\mathrm{O}_{2}$. Ber. Bunsenges. Phys. Chem. 1990, 94, 1375-1379.

(86) Koch, R.; Knispel, R.; Elend, M.; Siese, M.; Zetzsch, C. Consecutive reactions of aromatic-OH adducts with $\mathrm{NO}, \mathrm{NO}_{2}$ and $\mathrm{O}_{2}$ : benzene, naphthalene, toluene, $\mathrm{m}$ - and p-xylene, hexamethylben- zene, phenol, m-cresol and aniline. Atmos. Chem. Phys. 2007, 7, 20572071.

(87) Atkinson, R. Kinetics and mechanisms of the gas-phase reactions of the NO radical with organic compounds. J. Phys. Chem. Ref. Data 1991, 20, 459-507.

(88) Kahan, T. F.; Kwamena, N. O. A.; Donaldson, D. J. Heterogeneous ozonation kinetics of polycyclic aromatic hydrocarbons on organic films. Atmos. Environ. 2006, 40, 3448-3459.

(89) Finizio, A.; Mackay, D.; Bidleman, T.; Harner, T. Octanol-air partition coefficient as a predictor of partitioning of semi-volatile organic chemicals to aerosols. Atmos. Environ. 1997, 31, 2289-2296.

(90) Odabasi, M.; Cetin, B.; Sofuoglu, A. Determination of octanolair partitioning coefficients and super-cooled liquid vapor pressures of polcyclic aromatic hydrocarbons as a function of temperature: application to gas-particle partitioning in an urban atmosphere. Atmos. Environ. 2006, 40, 6615-6625.

(91) van Noort, P. C. M. A thermodynamics-based estimation model for adsorption of organic compounds by carbonaceous materials in environmental sorbents. Environ. Toxicol. Chem. 2003, 22, 11791188.

(92) Lei, Y. D.; Chankalal, R.; Chan, A.; Wania, F. Super-cooled liquid vapor pressures of the polycyclic aromatic hydrocarbons. $J$. Chem. Eng. Data 2002, 47, 801-806.

(93) Feilberg, A.; Kamens, R.; Strommen, M. R.; Nielsen, T.; Holcman, J.; Sehested, K. Atmospheric oxidation of nitro-polycyclic aromatic compounds and nitro-substituted NPAC in water droplets. Polycyclic Aromat. Compd. 1999, 14-15, 137-150.

(94) Zhang, L.; Gong, S.; Padro, J.; Barrie, L. A size-segregated particle dry deposition scheme for an atmospheric aerosol model. Atmos. Environ. 2001, 35, 549-560.

(95) Pryor, S. C.; Gallagher, M.; Sievering, H.; Larsen, S. E.; Barthelmie, R. J.; Birsan, F.; Nemitz, E.; Rinne, J.; Kulmala, M.; Grönholm, T.; Taipale, R.; Vesala, T. A review of measurement and modelling results of particle atmosphere-surface exchange. Tellus, Ser. B 2008, 60, 42-75.

(96) Scire, J. S.; Strimaitis, D. G.; Yamartino, R. J. A user's guide for the CALPUFF dispersion model (version 5), 2000, www.lem.org.cn/ u/cms/www/201307/05161203d9ap.pdf.

(97) Tartakovsky, D.; Broday, D.; Stern, E. Evaluation of AERMOD and CALPUFF for predicting ambient concentrations of total suspended particulate matter (TSP) emissions from a quarry in complex terrain. Environ. Pollut. 2013, 179, 138-145.

(98) Lee, J. A.; Hacker, J. P.; Monache, L. D.; Kosovic, B.; Clifton, A.; Vandenberghe, F.; Rodrigo, J. S. Improving wind predictions in the marine atmospheric boundary layer through parameter estimation in a single column model. Mon. Weather Rev. 2017, 145, 5-24.

(99) Feilberg, A.; Nielsen, T. Effects of aerosol chemical composition on the photodegradation of nitro-PAHs. Environ. Sci. Technol. 2000, 34, 789-797. 